Linguistik Terapan 18 (1) (2021): 48 - 62

Jurnal Linguistik Terapan Pascasarjana

Available online

http://jurnal.unimed.ac.id/2019/index.php/JLT-Unimed

\title{
THE EFFECT OF COLLABORATIVE WRITING TECHNIQUE AND BRAINSTORMING TECHNIQUE AND STUDENTS CURIOSITY ON STUDENTS WRITING ACHIEVEMENT
}

\author{
Dina Maryadi Nasution \\ Anni Holila Pulungan \\ Siti Aisah Ginting
}

English Applied Linguistic Program

Postgraduate Program - Universitas Negeri Medan

Diterima Desember 2020; Disetujui Februari 2021; Dipublikasikan April 2021

\begin{abstract}
The objective of this research is to explain wheter are students' writing achievement taught by using collaborative writing technique is higher than that taught by using brainstorming writing technique. Because students more than active to make writing cooperatively. While the brainstorming writing technique ordered the students to make writing individually. The research design was experimental with research by using factorial design $2 x$ 2. There were 34 students from 2020/2021 academic year of Madrasah Aliyah Swasta Awashliyah 30 Binjai as the sample of this research.the students were divided into two groups. The first group was treated by using collaborative writing technique and the second group was treated by using brainstoring writing technique in writing achievement. The data were analyzed by applying ANNOVA. The result of the research that student's writing achievement high curiosity with the mean score 83.35 higher than those with low curiosity eith the mean score is 82,29 and the $F_{\text {observed }}=$ $65.680>F_{\text {table }} 0.002$. It means that students with high curiosity affect students writing achievement higher than students with low curiosity.
\end{abstract}

Keywords: Writing TeachingTechniques, Students' Curiosity, Writing Achievement

How to Cite: Maryadi Nasution, Dina. (2021). The Effect of Collaborative Writing Technique and Brainstorming Technique and students Curiosity on Students Writing Achievement. Jurnal Linguistik Terapan-Pascasarjana Unimed. 18(1): 48 - 62

ISSN: 2407 - 7410 


\section{INTRODUCTION}

The Implementation of the Curriculum 2013, English language skills are formed through continous learning. It starts with improving the knowledge competency of the types, rules and context in a text followed by competency skills that present a written and spoken text. The both planned and spontaneous with the correct pronounciation and intonation. They leads to the formation of langauge politeness and respect for the language. Then, the goverments sets Competency Standart of Graduates (SKL) through Permendikbud No. 54 of 2013. Competency standart of Graduates have three qualifications abilities that include attitude, knowledge and skills.

To make the teaching writing succesful, the teacher should give their attention about the way in making the teaching writing effective. Such as strategy, method, technique and matery for teaching writing. Teacher also should pay attention to the other skills that the students need before because teaching writing is a complex.

In the reality, activities in teaching and learning process in tenth grade of SMA Cerdas Murni Tembung, English teacher used the old stretegies, method and technique such writing was ussually done in long time. But students could not procedure enough words and sentence in their writing. Based on the reseacher's preliminary study and observation through interviewed to the English teacher in that school, the problem can see in the following phenomena. Some students were not interesting in writing, some students did not have enough ability to write, some of students could not express their ideas in written form, some of students often wrote ungrammatically, and a teacher is always monotouns in his teaching performance, wich is the teacher still use lecture method in the class, the teacher always ordered the students to do the exercise in text book without using another way to make the students be more interest, active and creative.

Based on preliminary data of students' score in students' writing, the students' score of writing descriptive text in semester 2 in academic year 2019/2020 also still does not fulfill the minimum passing grade (KKM) that is 75 .

The score of the students in the both of classess (XA and XB ) still low. In the class XA there are 30 students. In that class the students who get the passing grade are 8 students, then there are 22 students who get under paasing grade. In class XB there are also 30 students. In that class the students who get passing grade are 11 students. Then, there are about 19 students who get under passing grade. 
Based observed reseracher to the English teacher on the total score of making descriptive text by students before. The mean score of those classes are :

\section{Table 1.1 The Mean Score of Descriptive Text by Tenth Grade Students of} MAS Al-Washliyah 30 Binjai

\begin{tabular}{ccc}
\hline Class & Mean Score & Percentages \\
\hline XA & 67 & 27 \\
\hline XB & 69 & 37 \\
\hline
\end{tabular}

From Table 1.1 shown the scores of both classes based on the total number of students that average score from both classes still under KKM. Based on the previous data by Nawawi (2011:1) stated that in descriptive text the students may have difficultties in learning. They confused what to write although they know the topic. Nesia(2017:3 ) stated that collaborative technique can be used to improve the students' writing ability. Then, collaborative gives oppurtunities for students to share and develop the ideas more easily.Yenita (2014:2) Descriptive text is usually used in daily life such as, describing place to someone new, describing a person, or describing thing. Many students find difficulties in writing descriptive text. To solve the problems that have been mentioned above, the writer tries to give easy way to write descriptive text by using collaborative technique. In this technique ,students usually work in groups of two or more, mutually searching for understanding, solutions, meaning, or creating the product. Rahmawati (2019:2) states that brainstorming technique give some positive effect on students writing achievement especially in descriptive text. Those five aspect are content, organization, grammar, vocabulary and mechanic. It is show in mean score in pre-test was 62,48 then mean score in post-test was 73,50. It means that the students mean score improved about 11.02 .

Based on the phenomena mentioned above. It is clear that most of students had alot problems in processing of writing. especiallly in writing on descriptive something. In solving problems encountered by students, using techniques is one of the solution. In this era, there are so many issues developing and develop by some experts. Some expert claim that collaborative writing technique and brainstorming technique can solve the problem above. Because those techniques are way of learning process in production of ideas in writing. So that, there are two techniques in writing skill will be discussed to help students developing 
their ability to write and raise their acievement. Those are collaborative writing technique and brainstorming technique.

Collaborative writing. is a process of writing that is done by a group or pair. It has many adventages such as writers can share experience and knowledge, give support and help to the members of the group and finish writing work faster,

Brainstorming is the simples method of generating ideas, the most versatile, and probably the most commonly used by students. Essentially, brainstorming is just what the word s suggest. It makes ideas flow and appear easily in students' mind when they begin to write.

Beside teaching technique factor above, another factors that influence of writing in the students own personality. On of the personality that includes and related in learning process is curiosity. Curiosity is define as a desire for new information aroused when a person become aware of uncertainty in the environment and of novel, complex and/ $r$ ambiguous stimuli that can lead to exploration and learning. In learning, curiosity provides the motivational fuel for learning at each step of the educational process. When students have curiosity, they learn more and more about their lesson and as a result, are closer connected to it.

Based on the explanation on the background of the study before, the objective of the research is formulated as in the following:

To describe the students' achievement with high curiosity significantly higher than those low curiosity taught by using Collaborative Writing Technique and Brainstorming Technique.

The research objective is formulated to answer the following problem of the research: Is students' writing achievement with high curiosity significantly higher than that low curiosity taught by using Collaborative Writing Technique and Brainstorming Technique?

The scope of the research is confined in using the both of two teaching techniques in writing, those are collaborative writing technique and brainstorming technique. Then, the researcher will also measure from the own personality of student. That is curiosity. By knowing high and low curiosity of students, this research is ecpected to give clear description on the effect of teaching techniques and curiosity on students achievement in writing. The writing genre observed in this research focuses on descriptive writing which should be achieved by the students of grade ten as what is required to be learnt in curriculum in MAS Al-Washliyah 30 Binjai. 


\section{A. Students Achievement}

Brown (2004) states an achievement is a process of developing skills or knowledge. The most common type of achievement is a standarized progress indeveloping the measurable skills and knowledge learned in the given level, usually through planned instructions, such as training or classroom instruction.

Based on the opinions above, it can be concluded that achievement is the result, the successfulness, the extent or ability, the progress in learning education experiences that the individual indicates relation with his/her educational learning. Achievement concerns with what someone has actually learnt whereas aptitude is the potential for learning something. In other words, achievement is a success in reaching particular goal/status or standard, especially by effort, skill, courage, and so on.

\section{B. Writing}

Writing is one of the productive skills which are closely bound up with the receptive skill work (Harmer, 2001:250). Writing due not only to the need to generate and organize ideas using appropriate choise of vocabulary, sentence, grammar, and paragraph organization but also to turn such ideas into a readable text. (Richard and Renandya, 2002: 303).

To teach writing successfully, the teacher should know some approaches can help and affect the successfull of teaching writing in the class because the teacher be able and apply to the appropriate approach learning yo teach material. there are two kind of approaches, namely Teacher- center approach and Studenrt-centre approach (Al-Zu'Be:2013)

Brown (2001: 335) says product assessment focuses on assessing the students' final composition, while Hyland (2003: 226) states that writing product can be assessed through employing some methods of scoring. There are three types of rating scales generally used in scoring writing. They are holistic, analytic, and trait-based scoring. In this study, the researcher choose the trait-based scoring.

\section{Techning Techniques of Writing}

There are some techniques of writing which the purpose is as a references for the teacher to teaching writing in classroom to developt the students writing. These techniques are collaborative writing technique and brainstorming technique.

\section{a. Collaborative writing}

Collaborative learning involves learners interacting in pairs or small group on a writing task. Thus the two key components in collaborative writing are verbal interaction and 
writing. verbal interaction hasbeen identified as fundamental in both cognitive and sociocognitive theories of second language (L2) learning. The act of writing also has language learning potentials. The cognitive proces that occur in the production of written language (Storch,2013)

Alwasilah (2000) stated there are some steps of collaborative writing, as follows :

1) Ideas, To help students understand the importance of components in text essays such as characters, settings, problems, and solutions, students are given the following complete questions, the majority of which begin with the question word "WH" (who, what, where, when, why, and how) . The aim is to build on the writer's ideas.

2) Drafting, the keywords that have been written in the first step are then developed into a draft essay.

3) Reading, writer reads the draft writing aloud. When reading a pronunciation / reading error, the helper is allowed to correct the error if he is able.

4) Editing, the helper and writer look back at the draft that has been prepared. At this stage they can make improvements that are felt necessary by both. Errors of words, phrases, or sentences should be marked by using a color pen or stabile to facilitate subsequent repairs. There are five things that must be considered in editing this initial draft, which are: meaning, order, style, spelling, and punctuation.

5) Final Draft, after that the writer rewrites the edited text in accordance with the advice and input from the helper. The helper can provide assistance when needed. The final results of this paper become the results of group work which is then submitted to the teacher.

6) Teacher Correction, in this stage students will get instructive comments and feedback from the teacher. Students should face the teacher together to get the teacher's correction in grammar and feedback related to meaning / ideas, orders, style, spelling, and punctuation (punctuation)

Alwasilah (2000), pointed collaborative writing has advantages as follows:

(a) Instill cooperation and tolerance for the opinions of others and increase the ability to formulate and express ideas;

(b) Instilling the attitude of writing as a process because group work emphasizes revision, allowing students who are weaker to recognize the writings of friends;

(c) Encourage students to learn in group work, and present the work situation they will experience in the professional world in the future 
(d) Getting used to self-correction and writing drafts repeatedly, where students as writers are the most loyal readers.

In addition to the advantages above, the collaborative writing has weaknesess, as follows :

(1) The difficulty of getting colleagues who can work together,

(2) In group work often there are too many alternatives or suggestions for improvement that are confusing

(3) Spent a lot of teacher and student time

\section{b. Brainstorming Technique}

Brown (2001: 184) states brainstorming as a technique which helps someone initiate some sort of the thinking process. Brainstorming is often put to excellent use in preparing students to read a text, discuss a complex issue, or write on a topic. Scarry and Scarry (2008: 8) define brainstorming as a technique in which a student uses free association to discover ideas come to mind on a given topic. It is a mental exercise in which a student writes down ideas about a topic. It can be a powerful method in the development of ideas.

Blanchard and Root (2003: 41) mention the steps of brainstorming.

1) Brainstorm list. In this step, the writer quickly makes a list of every word, every phrase, every ideas that comes into the writer's mind about the topic.

2) Edit brainstorming list. In this step, the writer includes in the final paragraph and what he/she want $t$ omit by combining ideas.

3) organize the list. Here, the steps should be in time order

4) Making an outline. Here, the title is centered at the top. The topic sentence is placed below the title and the five steps listed under the topic sentence and have capital letters.

5) Writing the paragraph. The last step is to write the paragraph based on the outline made.

According to Roestiyah (2012) the following are the advantages and disadvantages of using brainstorming technique in teaching writing:

a. Advantages using brainstorming technique:

1) The students think actively to express opinion.

2) Training the students to think fast and logically systematic.

3) Stimulating the students should always be ready to argue that relate to the problem given by the teacher.

4) Increasing the student's participation in accepting the lesson.

5) The active/less students get help from their smarter friends or from the teacher. 
6) Create a fair competition.

7) The students feel free and happy.

8) The atmosphere of democracy and discipline can be grown.

b. Disadvantages using brainstorming technique:

1) The teacher was not giving time to the students to think well.

2) Sometimes the conversation is just monopolized by smart students.

3) The teacher simply holds opinion, but never said the conclusion.

4) The students do not immediately know whether his opinion was true or false.

5) Problems can develop in ways that are not expected.

\section{Curiosity}

Jonathan (2012:11) proposed four theories related to the nature of curiosity. His further explanation of related theories can be seen in the following table :

Table 2.2 The Nature of Curiosity

\begin{tabular}{ccl}
\hline No. & Theory & \multicolumn{1}{c}{ Summary } \\
\hline 1 & Drive & Curiosity is human drive, comparable to hunger and thirsty \\
\hline 2 & Incongruity & $\begin{array}{l}\text { Curiosity is evoked by incongruity between something (an } \\
\text { event, object, etc) and person's existing knowledge }\end{array}$ \\
\hline 3. & Gap & $\begin{array}{l}\text { Curiosity arises when someone become aware of a gap } \\
\text { between his or existing set of informationand some other } \\
\text { desire information }\end{array}$ \\
\hline 4. & Tactile & $\begin{array}{l}\text { Curiosity arises from physical engagement with things we } \\
\text { believe we might change }\end{array}$ \\
\hline
\end{tabular}

\section{a. Low and High Curiosity on Students' Learning}

Kashdan (2009) identified some characteristics of students with high curiosity toward learning, they are ; 1) students always interested in new things and processing an open and receptive attitude toward whatever is the target of attention, 2) students will devote more attention to an activity, process information more deeply, remember information better, and are more likely to persist on tasks until goals are met, 3) students will have the ability to effectively cope with or make sense of the novelty, ambiguity and uncertainty being confronted during explorations, 4) students like to express the exploration as the willingness to embrace the novel, uncertain and unpredictable nature of everyday life, 5) students like in 
spending time with novel stimuliis exposed to some degree of informationand experiences, 6) students actively seeking understanding about something that unknown.

Meanwhile, characteristic of students with low curiosity toward learning are ; 1) students have sequencing difficulties are evidanced in a failure to grasp time concepts, 2) students will lose tract of assignments and attendance and stuggle to concentrate, 3) students have experience cognitive confusion in the presence of distracting stimuli, demonstrate poor organizationational skill, and find it hard to refocus after losing concentration, 4) students have low interestin detail and non participation in class activities, 5) students have difficulty to solve the problem that puzzle them, 6) less of these sense of wondering and challenging to explore an uncertainly.

\section{b. The Measurement of Students' Curiosity}

Researcher has to select or develop scales and instruments that can measure characteristics such as intelligence, achievement, personality, motivation, attitudes, aptitudes, interest, and so forth. Diffrent devices are used for qualifying diffrent qualities. One way of obtaining is simply to ask questions. The questionnaire utilizes this approaches.

Written questionnaire is used to obtain data of students' curiosity. This type is typically more efficient and practical and allows fo the use of larger sample. To measure the students'curiosity, the questionnaire is constructed based on the curiosity's indicator. In this research are attention in learning, motivation as learning desire to have the competition to successed in learing, and the desire to have books related to the lesson), the willingness (willingness in doing the task and the students' absence in learning activity), and enjoying in the process of learning.

\section{E. Descriptive Text}

I Wy. Dirgeyasa (2016 : 58) stated that the genre based descriptive writing also has its own rhetorical structure or gereneric structure and textual elements. Then, each element has its own fuction and pupose.

a. The generic structures and textual elements: 
Table 2 The Generic Sturures and Textual Elements

\begin{tabular}{|c|c|}
\hline $\begin{array}{c}\text { Textual } \\
\text { Elements }\end{array}$ & Functions \\
\hline Identification & $\begin{array}{l}\text { - It is a statemnet } \\
\text { describing and ilustrating } \\
\text { about the topic/ theme to } \\
\text { be decribe } \\
\text { - Statement must be } \\
\text { interesting and is able to } \\
\text { attract and to provoke the } \\
\text { reader so that the reader } \\
\text { becomes interested in } \\
\text { reading the complete } \\
\text { description } \\
\text { The use of adjective and } \\
\text { degree of comparison of } \\
\text { adjective is advisible }\end{array}$ \\
\hline Description & $\begin{array}{l}\text { - It is a complete } \\
\text { description about the } \\
\text { topic/theme proposed in } \\
\text { identification text. } \\
\text { - Description is the detai } \\
\text { description or elaboration } \\
\text { of the topic or theme as } \\
\text { described in the } \\
\text { identification }\end{array}$ \\
\hline
\end{tabular}

b. The generic features of description are:

1. Verb in the present tense

2. Adjective to describe the features of the subject

3. Topic sentences to begin paragraphs and organize the various aspects of the description.

\section{METHODOLOGY}

This research was carried out by applying a quantitative approach with an experimental design. In this research, there is one independent variable: that was teaching techniques, which are two kinds: Collaborative Writing Technique and Brainstorming technique. While dependent variable was the students' achievement in writing. Thus, the research design is two- way ANOVA (Analysis Of Variance).

The population of this research was all grades ten in MAS Al-Washliyah 30 Binjai, consist three classes. Each class consists of 34 students; it means that 102 students were used 
as the population of this research. The sample of this research were 68 students found in 2 classes randomized from tenth classes. This was taken based on the random sampling. Which is like lottery. The researcher prepare three pieces of paper in a box and then sellect two piece paper. Those paper ware class XA and XB.

In order to get some data that were needed to suppoet this research. The researcher applied the technique of collecting data using Writing test. The test was about writing English which was appropriate with their in-use curriculum. This instrument was used to collect the data in order to find out di diffrence between collaborative writing and brainstorming techniques on write descriptive text as a product by students. The researcher used writing test by giving some the name of place famous in the Indonesia. Then the students will describe the place.

\section{FINDING AND DISCUSSION}

\section{A. The Effect of High and Low Curiosity on Students' Writing Achievement}

Table 4 The calculation of the effect of High and Low Curiosity

\begin{tabular}{cccc}
\hline No. & Data & $\begin{array}{c}\text { High } \\
\text { Curiosity }\end{array}$ & $\begin{array}{c}\text { Low } \\
\text { Curiosity }\end{array}$ \\
\hline $\mathbf{1}$ & $\mathrm{N}$ & 34 & 34 \\
\hline $\mathbf{2}$ & Maximum & 95 & 84 \\
\hline $\mathbf{3}$ & Minimum & 70 & 64 \\
\hline $\mathbf{4}$ & Mean & 83,35 & 82,29 \\
\hline $\mathbf{6}$ & Median & 86 & 84 \\
\hline $\mathbf{7}$ & Mode & 74 & 74 \\
\hline $\mathbf{8}$ & $\begin{array}{c}\text { Std. } \\
\text { Deviaton }\end{array}$ & 8.886 & 9.081 \\
\hline $\mathbf{9}$ & Variance & 78.963 & 82.456 \\
\hline
\end{tabular}

The calculation of the effect of high and low curiosity as follows in Table 4 Students with who have curiosity with mean score is 83.35 . While students who have high curiosity with mean score is 82.29 . it means that students with high curiosity affect to students writing achievement higher than students with low curiosity. 


\section{B. Result of Students Writing Achievement with High Curiosity}

The score on the students achievement in writing descriptive with high curiosity can be explained mean score is 83.35 . The score are shown in table 4.2

Table 4.2 Frequency Distribution of the score of Students Taught by Using Collaborative

Writing Technique

\begin{tabular}{ccccc}
\hline & $\begin{array}{c}\text { Frequ } \\
\text { ency }\end{array}$ & $\begin{array}{c}\text { Per } \\
\text { cent }\end{array}$ & $\begin{array}{c}\text { Valid } \\
\text { Percent }\end{array}$ & $\begin{array}{c}\text { Cumulative } \\
\text { Percent }\end{array}$ \\
\hline 64 & 1 & 2.9 & 2.9 & 2.9 \\
68 & 2 & 5.9 & 5.9 & 8.8 \\
70 & 1 & 2.9 & 2.9 & 11.8 \\
74 & 5 & 14.7 & 14.7 & 26.5 \\
76 & 1 & 2.9 & 2.9 & 29.4 \\
78 & 1 & 2.9 & 2.9 & 32.4 \\
80 & 1 & 2.9 & 2.9 & 35.3 \\
82 & 2 & 5.9 & 5.9 & 41.2 \\
Valid & 2 & 5.9 & 5.9 & 47.1 \\
86 & 2 & 5.9 & 5.9 & 52.9 \\
88 & 5 & 14.7 & 14.7 & 67.6 \\
90 & 3 & 8.8 & 8.8 & 76.5 \\
& 3 & 8.8 & 8.8 & 85.3 \\
92 & & & \\
94 & 5 & 14.7 & 14.7 & 100.0 \\
To & 34 & 100.0 & 100.0 & \\
tal & & & & \\
\hline
\end{tabular}

Table 4.2 indicates that the average scores of students' achievement in writing with high curiosity were interval 86 with 2 students or $5.9 \%$. From 34 students, 16 students or $47.1 \%$ got score below average and 18 students or $52.9 \%$ got scores above the average scores. 
The clear description of the scores was distribution can be seen in figure 4.1

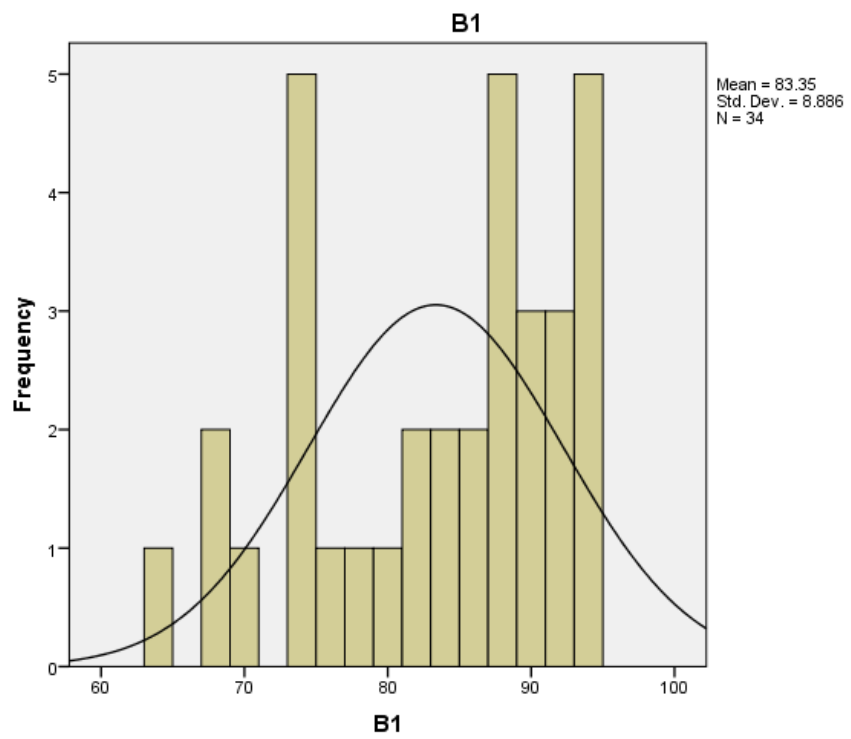

Figure 4.1 Histogram on Students' Writing Achievement with High Curiosity

\section{Result of Students Writing Achievement with Low Curiosity}

The score on the students achievement in writing descriptive with low curiosity can be explained mean score is 82.29 . The score are shown in the table 4.3

Table 4.3 Frequency Distribution of the score of Students Taught by Using Collaborative

Writing Technique

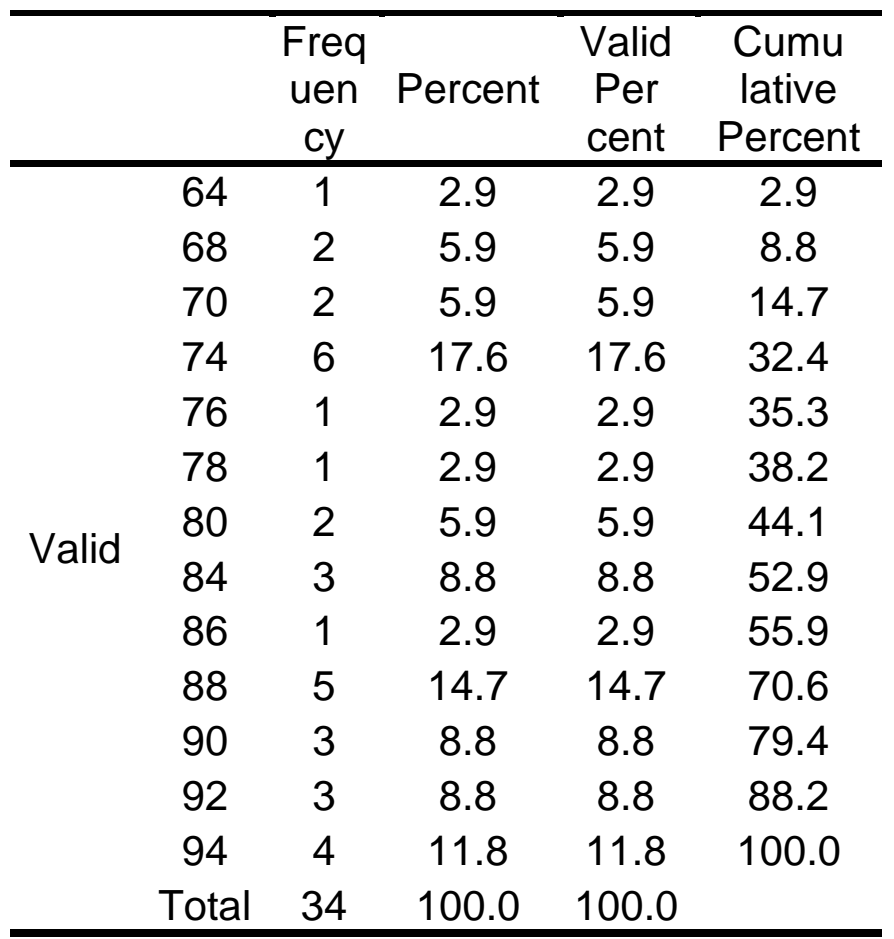


Table 4.3 indicates that the average scores of students' achievement in writing with low curiosity were interval 84 with 3 students or $8.8 \%$. From 34 students, 2 students 15 or 44.1 $\%$ got score below average and 19 students or $55.9 \%$ got scores above the average scores.

The clear description of the scores was distribution can be seen in figure 1

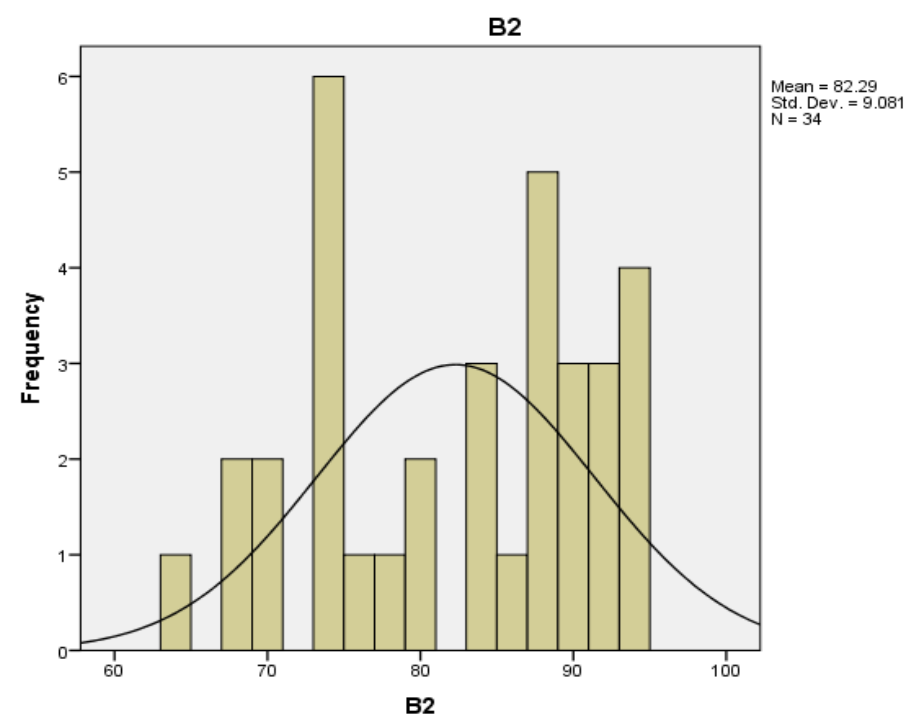

Figure 1 Histogram on Students' Writing Achievement with High Curiosity

\section{CONCLUSIONS}

Based on the data analysis and the research findings, it is concluded that:

The students' achievement in writing descriptive text of the students who have high curiosity was higher than students who have low curiosity.

There is a suggestion related to the conclusion at the previous page. That is:

a. It is suggested for the teachers to use Collaborative Writing Technique and Brainstorming technique are able to improve students' achievement in descriptive writing.

b. Other researchers may take a further research in the area Collaborative Writing Technique and Brainstorming technique that will improve students' achievement in descriptive writing 


\section{REFERENCES}

Alwasilah, A. Chaedar. (2000). Perspektif Pendidikan Bahasa Inggris di Indonesia dalam Konteks Persaingan Global. Bandung: Andira.

Arikunto, S. (2006). Prosedur Penelitian Suatu Pendekatan Praktik (Edisi Revisi Vi). Jakarta: Pt Rineka Cipta.

Ary.Et.Al. (2010),Introduction To Research In Education : Eight Edition. Usa:Wadsworth.

Backer, Jeanine, M. And Friends. (2018).The Effects of Collaborative Grouping on Student Engagement In Middle School Students.Masters Of Arts In Education Action Research.St. Catherine University.

Blanchard, K. \& Root, C. 2003. Ready to Write: A first Composition Text (Third Edition). New York: Pearson Education.

Brown, H Douglas. (2001).Teaching by Principle An Interactive Approach to Language Pedagogy. San Francisco: Longman

Clark, Irene L. (2003). Concepts in Composition: Theory and Practice in the Teaching of Writing. London: Lawrence Erlbaum Associates Publisher.

Dirgeyasa, I Wy. (2018). College Academic Writing A Genre-Based Perpective. Jakarta: Prenadamedia Group.

Irwandi,(2016).THE Use Of Collaborative Writing Technique To Improve Students' Ability In Writing Descriptive Text. Journal of Education Language Teaching Language,3(2).60-75

Minawati. Candra,(2018), Brainstorming Technique To Improve Writing Skill In Descriptive Texs Of Vocational High School Students, Journal of Education, 33-44

Norseha Unin,(2016), Brainstorming as a Way to Approach Student-Centered Learning in the ESL Classroom. Procedia - Social and Behavioral Sciences,224,605-612.

Rahmawati.Eva,(2019), The Effect Of Brainstorming Technique As A Prewriting Activity On The Students' Achievement In Writing Descriptives Text At Sman 1 Pringsewu. Faculty Of Teacher Training And Education University Of Lampung

Richards, J.C. And Renandya, W.A. (Ed.). (2002). Methodology In Language Teaching: An Anthology Of Current Practice. Cambridge: Cambridge University Press.

Roestiyah. (2012) Strategi Belajar Mengajar.Jakarta. Rineka Cipta 